\title{
Attitudes of Jordanian Undergraduate Students Towards Using Computer Assisted Language Learning (CALL)
}

\author{
Farah Jamal Abed Alrazeq Saeed ${ }^{1}$, Norma Nawaf Al-Zayed ${ }^{2 *}$ \\ ${ }^{1}$ Freelance Translator, ${ }^{2}$ Assistant Professor, Department of English at Middle East University, Faculty of Arts and Sciences, Amman, Jordan
}

Corresponding author: Norma Nawaf Al-Zayed, E-mail: dr_normaalzayed@hotmail.com

\section{ARTICLE INFO}

Article history

Received: August 06, 2017

Accepted: January 01, 2018

Published: January 31, 2018

Volume: 6 Issue: 1

Conflicts of interest: None

Funding: None

\begin{abstract}
The study aimed at investigating the attitudes of Jordanian undergraduate students towards using computer assisted -language learning (CALL) and its effectiveness in the process of learning the English language. In order to fulfill the study's objective, the researchers used a questionnaire to collect data, followed-up with semi-structured interviews to investigate the students' beliefs towards CALL. Twenty- one of Jordanian BA students majoring in English language and literature were selected according to simple random sampling. The results revealed positive attitudes towards CALL in facilitating the process of writing assignments, gaining information; making learning enjoyable; improving their creativity, productivity, academic achievement, critical thinking skills, and enhancing their knowledge about vocabulary grammar, and culture. Furthermore, they believed that computers can motivate them to learn English language and help them to communicate and interact with their teachers and colleagues. The researchers recommended conducting a research on the same topic, taking into consideration the variables of age, gender, experience in using computers, and computer skills.
\end{abstract}

Key words: Attitudes, Computer-assisted Language Learning (CALL), Undergraduate Students

\section{INTRODUCTION}

With English becoming an international lingua franca, the number of ESL (English as a Second Language)/EFL (English as a Foreign Language) learners worldwide is in constant increase. In such circumstances, it can be clear that these students are in need of support in their process of learning the language. Thus, it is necessary to search for modern and technological methods and tools for practicing the language along with its skills in order to make the language learning process easier and more efficient.

When talking about technological tools, it should be noted that we have recently witnessed a development in the use of technology, especially computers, to a point that we are living in what we can call a "digital world". Computers have invaded many fields, such as the fields of administration, engineering, medicine, industry and above all the field of education since the 1960s. Technology itself is nothing but a tool to assist and guide learning. Teaching is mostly what teachers do and learning is mostly what students do; technology is a vehicle. Teacher training is a key solution to success in the effectiveness of implementing CALL in educational context.

Computers have spread worldwide in the field of education, at schools, universities and colleges to a point that they have led some scientists to suggest that computers might replace the teacher one day in the future, and educational institutions might use them to teach all subjects, including language skills and literature courses in many places. AbuSeileek and AbuSa'aleek (2012) say that: "Computers are becoming an increasingly significant element in the teaching and learning of foreign languages and in the study of English as a second and foreign language" (p.24).To add more, many institutions that have facilities and special labs that are well equipped with computers to teach languages, while other facilities contain computers in every lecture hall or classroom. Furthermore, we can find language curricula that were especially designed to be taught with the use of the computer.

With the spread of using computers in the language learning process, the term computer- assisted language learning (CALL) has emerged in the second half of the $20^{\text {th }}$ century to refer for the use of computer in the process of learning any language or any of its skills. The spread of using CALL led many scholars to investigate the advantages of using CALL upon the people who are involved in the process (students, instructors and teachers)

For instance, many scholars believed that using it shall help ESL/EFL students to learn interactively and shall improve the quality of the language learning process and outcomes. There is also much evidence supporting the fact that attitudes can impact the learner directly or indirectly (Ajzen $\&$ Fishbein, 1988). 


\section{Statement of the Problem}

There are many studies that were conducted to investigate the effectiveness of CALL. Some of these studies found it highly effective and very beneficial. However, other studies doubted its effectiveness and found it the opposite and as being costly and with many barriers that limit using it. Thus, this study came to investigate the extent of CALL's effectiveness and evaluate it from the Jordanian BA students' point of view, because the researchers believe it's highly important to investigate the opinions of the people who are involved in the CALL process. We need to make all the students influencing CALL implementation and success more visible, which is a future possibility only via extensive research.

\section{Research Questions}

This study aims to provide answers for the following questions:

1. What are the Jordanian undergraduate students' attitudes towards using computer assisted language learning CALL?

2. What are the differences and similarities in the learners' attitudes towards CALL?

\section{Significance of the Study}

The significance of this study lies in filling a gap in literature because to the best knowledge of the researchers, there is a lack in the studies that investigated the attitudes of Jordanian undergraduate students towards the use of CALL. The study's significance also arises from being beneficial for teachers, educators, university instructors, decision makers and curricula designers to encourage them towards integrating computers into the language learning process, in case this study confirmed the effectiveness of CALL. Furthermore, identifying students' attitudes towards CALL can be considered as an indicator in identifying the success of CALL in the future. It is shown that educational practice is in harmony with theories of learning by evaluating cooperative learning. It is argued that new technology offers a special potential for supporting the development of collaborative learning in education.

\section{THEORETICAL FRAME WORK}

It is highly important to refer to the theories that were suggested and introduced by researchers and linguistics that serve the objectives of my research. Gündüz (2005) indicates that computers are very helpful regarding the development of students' writing skills; computers can help to generate ideas when getting prepared to write. The impact of computers upon writing skills can be attributed to having spelling checkers in programs. Thus, such programs will be beneficial for the students who are weak in spelling and will help them with a list of options in the correct possible words.

Dweik and Safadi (2007) believe that computers can help EFL learners in developing their four language skills and vocabulary. They believe that it promotes motivation, and individualization, and can provide a great number of information sources available between their hands. They also think that CALL can be reflected positively on the achievement and progress of EFL students.

Alduwairej (2010) investigated the attitude of US ESL university students towards using technology to learn English. The study was conducted at Cleveland State University. It included fifty students from three ESL classrooms. The researcher used a three part questionnaire; the first part was about the number of times of using technology in ESL classrooms. The second part was about the role of technology in ESL classrooms regarding the developing of the four language skills. As for the third part, it included open-ended questions which aimed to identify ESL students' attitudes' towards using technology in ESL classrooms. The researcher concluded that students preferred to use technology and they had positive attitudes towards using it in ESL classrooms. Students also believed that using technology can improve their four language skills and participation and shall also facilitate the process of learning.

Poursalehi et al. (2014) conducted the impact of CALL upon the speaking skills of 120 Iranian EFL learners at private language institutes. The researcher divided them equally in experimental and control groups randomly. The researcher taught speaking skills for the first group via computer (internet) and for the second group through a traditional method. The researchers adopted the instruments of pretest and posttest. The researcher found that CALL had a positive impact over improving the speaking skills of students.

Fatemi et al. (2015) inspected the impact of CALL on forty eight Iranian Lower intermediate EFL learners regarding the speaking and listening skills. It was an experimental study, which included two groups; experimental and control. The experimental group was provided with smart board, while the other group used white traditional board. They also aimed to see whether white smart boards have any effect on making the learning process autonomous and independent. The researchers used a pretest and posttest and a questionnaire. They concluded that listening, speaking, autonomy, and engagement in activities were improved through smart boards. In addition, CALL increased students' participation and involvement in activities, motivation and academic achievement. It provided an opportunity for experimental learning and made the language learning process autonomous.

Arishi (2016) explored the attitudes of Saudi industrial college students towards CALL. The sample included 70 Saudi male students. The researcher used two instruments. The first one was a questionnaire that aimed to identify the attitudes of students towards computer in general and its use. As for the second instruments, it was a questionnaire that aimed to identify students' attitudes towards CALL. The researcher concluded that students' attitudes towards CALL were positive. Students stated that CALL can increase their progress and achievement and make the learning process independent.

It is important to highlight that this study is just an introduction to investigating the role of language learning attitudes towards CALL. 


\section{METHODS}

\section{Sample of the Study}

The methodological approach adopted for this study is a qualitative and a quantitative one. The researchers chose twenty - one of Jordanian BA students majoring in English language and literature were selected according to simple random sampling. The sample age ranged from 18 to 23 . They were enrolled at the Middle East University.

\section{Instruments of the Study}

In order to fulfill the objective of this study, to collect the desired data the researchers adopted a questionnaire from Kitchakarn's (2015) study. This instrument contains (17) items that examine language learners' attitudes towards CALL. Each item is rated on a five-point Likert scale. It also includes 17 items to investigate students' attitudes towards CALL in improving their four language skills (listening, writing, speaking and reading) and their language areas (pronunciation, vocabulary and grammar). The questionnaire also elicits data on CALL's ability in developing their creativity, interaction, thinking skills, achievement, informa- tion, individuality in learning, and cultural knowledge. Vanwaewere and Desmet (2009) established the validity of the questionnaire using an exploratory factor analysis. For the internal reliability of the instrument, they reported a Cronbach's Alpha value of 0.801 .

In the current study, after gathering the questionnaires, the participants were followed up with semi-structured interviews to investigate their beliefs towards CALL and six participants accepted the invitation.

\section{RESULTS AND DISCUSSION}

\section{Results related to the first question}

1. What are the Jordanian undergraduate students' attitudes towards using computer assisted language learning CALL?

The results can be seen in details through Table 1 below: The aforementioned numbers of the arithmetic means were classified into positive, neutral and negative according to the following categories that are listed below: Positive: 3.68- 5/Neutral: 2.34- 3.67/Negative: 1 -2.33

Results revealed that most items in the questionnaire were assigned to language skills and sub-skills. They referred to

Table 1. Students' attitudes towards call

\begin{tabular}{|c|c|c|c|c|}
\hline Statement & Arithmetic mean & Percent & Rank & Level \\
\hline $\begin{array}{l}\text { 1. My attitudes towards using computer in the language learning process } \\
\text { are considered negative }\end{array}$ & 3.31 & 46.2 & 17 & Positive \\
\hline $\begin{array}{l}\text { 2. Using the computer makes me learn and do my assignments easier and } \\
\text { more convenient. }\end{array}$ & 4.0000 & 80 & 6 & Positive \\
\hline 3. Using the computer while doing activities or assignments saves time. & 3.9500 & 79 & 8 & Positive \\
\hline $\begin{array}{l}\text { 4. Using the computer helps me search and get information related to } \\
\text { English language and others from around the world. }\end{array}$ & 4.2381 & 84.6 & 4 & Positive \\
\hline $\begin{array}{l}\text { 5. Using the computer in learning English makes the learning process } \\
\text { more enjoyable }\end{array}$ & 4.6000 & 92 & 2 & Positive \\
\hline 6. Using the computer in learning English increases my creativity. & 3.7500 & 75 & 12 & Positive \\
\hline $\begin{array}{l}\text { 7. Using the computer in learning English increases my productivity and } \\
\text { improves my achievement. }\end{array}$ & 3.9524 & 79 & 7 & Positive \\
\hline $\begin{array}{l}\text { 8. Using the computer in learning English makes me as a learner more } \\
\text { autonomous and promotes individuality in the learning process }\end{array}$ & 3.24 & 64.8 & 15 & Neutral \\
\hline 9. Using the computer in learning English improves my critical thinking. & 4.6190 & 92.2 & 1 & Positive \\
\hline $\begin{array}{l}\text { 10. I have more opportunities to practice my writing skills while using the } \\
\text { computer. }\end{array}$ & 3.0476 & 60.8 & 16 & Neutral \\
\hline 11. While using the computer, I can improve my reading skills. & 3.4500 & 69 & 14 & Neutral \\
\hline $\begin{array}{l}\text { 12.Using the computer in learning English helps me learn and use new } \\
\text { vocabularies }\end{array}$ & 3.8571 & 77 & 10 & Positive \\
\hline $\begin{array}{l}\text { 13. Using the computer in learning English helps me practice my listening } \\
\text { and speaking skills and pronunciation easily. }\end{array}$ & 3.4762 & 69.4 & 13 & Neutral \\
\hline $\begin{array}{l}\text { 14. Using the computer in learning English helps me improve my } \\
\text { grammatical knowledge. }\end{array}$ & 4.52 & 90.4 & 3 & Positive \\
\hline $\begin{array}{l}\text { 15. Using the computer in learning English helps me communicate and } \\
\text { interact with my teacher and classmates easily. }\end{array}$ & 3.76 & 75.2 & 11 & Positive \\
\hline 16. Using computers in language learning can increase my motivation. & 3.92 & 78.4 & 9 & Positive \\
\hline $\begin{array}{l}\text { 17. Using computers in language learning can help me learn about the } \\
\text { culture of the target language and other cultures. }\end{array}$ & 4.0952 & 81.8 & 5 & Positive \\
\hline
\end{tabular}


reading, listening, speaking, writing, vocabulary, communication, and grammar. Language skills and sub-skills (grammar and vocabulary) can be improved by CALL. Technology is helpful in learning reading, vocabulary, listening, speaking, writing, grammar skills and communication skills. This agreement among the participants regarding language skills and sub-skills was much more evident in grammar and vocabulary. Although the same results were indicated for the other skills and sub-skills, the participants manifested lower confidence in approving the assistance of CALL in the learning process.

The items dealt with practicality, facility, essentiality of CALL and learners' anxiety autonomy, excitement, and attraction in CALL. The participants strongly agreed and agreed that CALL makes autonomous learning easier. Additionally, a large number of participants agreed that they do their homework through using computers, and nearly the same number of participants showed neutral agreement towards the helpfulness of computers for reading, listening, writing and speaking.

Furthermore, the participants of the study showed their strong and neutral agreement with gaining self-confidence using CALL). Finally, although a large number of participants believed that CALL does not make them feel uncomfortable and tense.

\section{Results related to the second question}

2. What are the differences and similarities in the learners' attitudes towards CALL?

When I face a grammatical problem, I google it right away, and I can find a lot of useful information about my problem easily and rapidly...I am not sure about speaking, but recently, I received a software in which I could check my speaking. I think it really helps improve my speaking. Students tried to add their own justifications rather than their experience for explaining the effects of CALL on different skills and sub-skills. Additionally, hedges were evident in their speeches which conveyed their uncertainty about the effects of CALL. Hence, however they emphasized on the supportive capabilities of computers regarding grammar and speaking, they did not believe computers are helpful on their own in this regard. (Interviewee 1)

I myself use computers to learn... I like learning English with new software. Once I attended an English institution which used computers for teaching English. It was so interesting to me. Afterward, I look for computer-based courses of English, I think because they help me learn English adapted to my interests. (Interviewee 2)

If we just use computers to learn English, we deprive ourselves of so many things, such as interacting with teachers, asking questions, or even finding new friends and talking to them. English is language and we cannot learn a language without communication with people. Computers are good assistants in this regard, but we feel like learning English when we learn it among other learners. (Interviewee 3)
I think, chatting with native speakers of English forces us to try to learn more vocabulary and grammar. That is because each time we want to speak to a native speaker; we need to prepare ourselves for interacting with them. Also, we indirectly absorb the native-speakers' way of speaking and the vocabulary and grammar he/she uses. (Interviewee 4)

Reliable databases in our field are very important. Whenever I want to learn about something, I search it in scientific databases. I look for relevant papers and download them if they are free. (Interviewee 5)

My eyes cannot follow lines of the online books and papers. I have to print it, and then read it. It is more enjoyable for me to be in the library; however, I know that computers let us be in contact with a wider range of materials for research...I like to search for the books I need and buy its hard copy read it in my bed... computers help in this regard. (Interviewee 6)

Although the last two students addressed their habits of reading and searching, and favored library- based research, they did not deny the influential effects of computers in helping students find their research and reading materials. As Dweik and Safadi (2007) believe, new technologies generate new concerns for educationalist and instructors. Hence, it is necessary for them to take appropriate measures to overcome the present problem on the way of the presentation of CALL into educational curriculum.

\section{CONCLUSION AND RECOMMENDATIONS}

In general, Jordanian BA students have shown their positive attitudes towards the use of CALL. They believe that it is able to facilitate the process of learning and doing assignments for them and can save them time while doing them. They also believe that computers enable them to get information and have numerous sources of information from all over the world, and able to make the learning process enjoyable. Furthermore, students believe that computers have the ability to increase and improve their creativity, productivity, academic achievement, and critical thinking skills. Students are also convinced that using computer in the language learning process can improve their vocabulary and grammar. However, their attitudes towards CALL impact over pronunciation are medium degree.

Furthermore, students have shown positive attitudes towards the role of computers in motivating them to learn English language. They are also convinced that CALL can improve their knowledge about the culture of the foreign language they are studying and other cultures.

On the other hand, students' attitudes are moderate towards using CALL for the purpose of improving their four language skills (listening, speaking, writing and reading) and their pronunciation. They also express medium degree attitudes towards the role of CALL in promoting individuality in learning English language. Having such a degree results can be attributed to having small sample size and the sample's incorrect comprehending of the instrument's statements. The results showed that students had positive attitudes toward all components of CALL, some differences 
were found in the degree of their agreement with the effects of CALL. The difference might stem from the requirements of learners' background learning experience, educational level, and learners' degree of awareness of language learning theories.

In the light of the aforementioned results further specific research in this regard should be conducted in the future. For instance, more studies are needed to investigate gender-related issues in CALL and developing curricula that are specially designed to be used with CALL.

\section{REFERENCES}

AbuSeileek, A. \& AbuSa'aleek, A. (2012). Computer assisted language learning: merits and demerits. Language in India, 12(4), 23-36.

Ajzen, I. \& Fishbein,M (1988). Understanding attitudes and predicting social behavior. Englewood Cliff NJ: Prentice-Hall.

Arishi, Sultan. (2016). Attitudes of students at Saudi Arabia's industrial colleges towards computer- assisted language learning (CALL), Teaching English with Technology, 12(1), 38-52.

Cubillos, J. H. (1998). Technology: A step forward in the teaching of foreign languages? In J. Harper, M. Lively, $\&$ M. Williams (Eds). The coming of age of the profes- sion: issues and emerging ideas for the teaching of foreign languages, (pp. 199-223). Boston: Heinle\&Heinle.

Dweik, B. and Safadi, R. (2007). Computers and EFL teaching: Advantages and disadvantages. Beirut: Association of English Teachers in Lebanon.

Fatemi, M; Alishahi, M; \&Esmaelzadeh, Nasib. (2015). The impact of computer assisted language learning on Iranian lower intermediate EFL learner's speaking and listening skills and autonomy. International Journal of Language Learning and Applied Linguistics World (IJL$L A L W), 8(2), 210-216$.

Gündüz, N. (2005). Computer assisted language learning (CALL). Journal of Language and Linguistic Studies, l(2), 120-163

Kitchakarn, O. (2015). EFL Learners'Attitudes towards Using Computers as a Learning Tool in Language Learning. The Turkish Online Journal of Educational Technology (TOJET), 14(2) $52-58$.

Poursalehi, J., Zohrabi, M. \& Zohrabi, M. (2014). The impact of computer assisted language learning (CALL) on Iranian learners' speaking skills, International. Journal of Language Learning and Applied Linguistics World (IJLLALW), 7(3), $494-500$.

Vanderwere, M., \& Desmet, P. (2009). Introductory psychometrical validation of questionnaire in CALL research. Computer assisted language learning, 22(7), 349-380. 